Arab Univ. J. Agric. Sci., Ain Shams Univ., Cairo, 13(2), 341 - 350, 2005

\title{
EFFECT OF NATURAL ANTIOXIDANT OF CAKE QUALITY DURING STORAGE
}

[21]

\author{
Ayman $^{1}$ E.M. and Nadia M. Abd El-Motaleb ${ }^{1}$
}

\begin{abstract}
In this study, both the methanol extraction of sage leaves and clove buds were added as natural antioxidant at concentraction 100, 200 and $300 \mathrm{ppm}$ from butter weight using in cake production. The cake produced was storage at room temperature for 8 weeks. Butter stability was measured by Rancimat apparatus. Also, peroxide value, acid value and thiobarbituric acid value were measured. Sensory evaluation was measured directly after baking (before storage) and at the end of storage period. Rancimat results showed that increasing natural antioxidant concentration led to longer butter stability and retarded rancidity than control. At the same time sage leaves extraction was much effectiveness for period long butter stability compared to clove buds extraction. Also the results revealed that the more concentration of natural antioxidants increased the peroxide value, acid value and thiobarbituric aicd value decreased compared to control. Sensory evaluation in zero time indicated improvement in taste, flavor, texture and tenderness while color values were decreased with increasing sage and clove extraction compared to control. After 8 weeks of storage sensory evaluation scores were generally decreased.
\end{abstract}

Key words: Methanol extraction of sage leaves and clove buds, Cake, Antioxidant activity, Sensory evaluation

\section{INTRODUCTION}

Consumers all over the world are becoming increasingly conscious of the nutritional value and the safety of their food and its ingredients. At the same time, there is an increased preference for natural foods and food ingredients which are generally believed to be safe, more healthy and less subject to hazards than foods containing artificial food additives. Lipid substances are easily deteriorated by oxidative rancidity from the reaction with atmospheric oxygen and hydrolytic reactions catalyzed by lipases from food or from microorganisms. Auto-oxidation and lipolysis are responsible for offflavors in lipid-containing food products (Allen and Hamilton 1983).

Antioxidants are compounds that can delay or inhibit the oxidation of lipids or other molecules by inhibiting the initiation or propagation of oxidizing chain reactions (Velioglu et al 1998).

1- Food Technology Research Institute, Agricultural Research Center, Giza, Egypt. 
Cake manufacturers face a major problem of lipid oxidation and mould growth which limits the shelf-life of their products. The use of antioxidants and preservatives can reduce this problem. Dietary antioxidants may also help counter the detrimental effects of oxygen free radicals, formed during normal metabolism and from external factors (pollution, radiation), which are implicated in the development of cancer (gene damage), premature aging, cardiovascular and other degenerative disease. However, four commercial synthetic antioxidants are reported as toxic to $\mathrm{KB}$ cells of human epidermoid carcinoma, propyl gallate (PG) as the most toxic, followed by BHA, BHT and DL- $\alpha$-tocopherol. Dietery BHA is also carcinogenic, causing fatal haemorrhages in the pleural cavities, peritoneal cavities and organs such as the epididymis, testes and pancreas of rats. At lower doses it affects the blood-clotting mechanism, impairs platelet function slightly and tends to depress lipo-peroxidation and polyunsaturated fatty acid pooling. A single large dose of BHT (100mg kg ${ }^{-1}$ ) produced some renal damage in rats, shown by reduced accumulation of $\mathrm{p}$ aminohippuric acid, proteinuria and enzymuria (Mochida et al 1986).

There are two basic categories antioxidants, natural and synthetic. Recently, interest has increased considerably in finding naturally occurring antioxidants for use in foods or medicinal materials to replace synthetic antioxidants, which are being restricted due to their carcinogenicity. Herbs have been used for a large range of purposes including medicine, nutrition, flavorings, beverages, dyeing, repellents, fragrances, cosmetics, charms, smoking, and industrial uses. Since prehistoric times, herbs were the basis for nearly all medicinal therapy until synthetic drugs were developed in the nineteenth century. Today, herbs are still found in $40 \%$ of prescription drugs (Smith et al 1996).

Rosemary, sage, thyme, marjoram and oregano among the herbs and clove, ginger, nutmeg and mace among the spices have strong antioxidant effects (Saito 1977).

The aim of this study is to evaluate the natural sources of antioxidants (instance leaves of sage and buds of clove extraction) in cake quality. The antioxidative activity by Rancimat apparatus, peroxide value, acid value and thiobarbituric acid value were determined during storage period for (8 weeks). Sensory evaluation of the produced cake was also evaluated.

\section{MATERIAL AND METHODS}

\section{Material}

- Leaves of sage (Salvia officinalis) and buds of clove (Syzygium aromaticum) were obtained from Medicinal Plants and Agricultural Seeds Harraz Company, Cairo, Egypt.

- Wheat flour (72\% extraction) was obtained from Middle and West El-Delta Mills Company.

\section{Methods}

- Sage and clove extraction were prepared according to method of Kim et al (1994) as follow: both of the dried herbs were individually ground to pass a 60-mesh sieve. Fifty $\mathrm{ml}$ of methanol was added to $5 \mathrm{~g}$ ground herb and shaken for $30 \mathrm{~min}$. at room temperature. The sample solution was allowed to stand 24 
$h$ at $5^{\circ} \mathrm{C}$ and then was filtered to obtain particle-free herb extract.

- Cake was prepared according to method of Lim and Suhaila (1999) with some modification by mixing creaming softened butter $(250 \mathrm{~g})$, sugar $(450 \mathrm{~g})$, salt $(1.5 \mathrm{~g})$ and $100,200 \& 300 \mathrm{ppm}$ from both of sage and clove extraction as natural antioxidant for $12 \mathrm{~min}$. at medium speed until light and fluffy. Whole eggs $(250 \mathrm{~g})$ were then slowly added at low speed to avoid curdling, the mixing bowl was scraped, and this was followed by continuous mixing for another minute. Sifted flour (500g) and baking powder $(9 \mathrm{~g})$ were then gently folded in at low speed for $1 \mathrm{~min}$. before the dough was mixed for another minute at medium speed. The dough was baked at $165^{\circ} \mathrm{C}$ for $30 \mathrm{~min}$. the cake was cooled, packed and stored at room temperature for 8 weeks.

- Butter was extracted from cake by soaking in n-hexan at room temperature for 48 hours. The extract was filtrated and evaporated to dryness. Butter was kept in deep freezer for further investigation. Butter was analysed at zero, 2, 4, 6 and 8 weeks for peroxide value (PV), acid value (AV) and thiobarbituric acid value (TBAV) according to methods of AOAC (1995).

- The antioxidative activities was examined by Rancimat apparatus (Model $679)$ at $100^{\circ} \mathrm{C}$ according to method of Karin and Hedda (1996).

- Color, flavor, taste, tenderness and texture of cake were sensory evaluated by ten panelists according to method of Amerine et al (1965).

- The obtained data were statistically analyzed using the SAS (1996).

\section{RESULTS AND DISCUSSION}

Concerning antioxidative activity the data in Table (1) showed that addition of sage and clove extraction to cake samples led to longer induction period and protection factor than control sample. From the same table it is obvious that sage extraction was greater induction period and protection factor than clove extraction. These results are in good agreement with data obtained by Farag et al (1989a). They studied effect of essential oils of sage and clove and their major constituents on emulsified linoleic acid in aqueous media to examine their antioxidant activity and found that those essential oils posses an antioxidant effect and this phenomenon was increased by increasing the concentration. Moreover they indicated that the effectiveness of various essential oils on linoleic acid oxidation was in the following descending order: sage $>$ clove. Besides Banias et al (1992) indicated that the high protective effect of sage on fat oxidation is considered to be primarily associated with presence of the phenolic diterpene carnosic acid. They also mentioned that, the basic compounds in extraction of sage and clove were Thujone and Eugenol respectively.

With respect to peroxide value (PV), acid value $(\mathrm{AV})$ and thiobarbituric acid value (TBAV) the results in Tables $(2,3$ and 4$)$ revealed that, the more concentration of sage and clove extraction increased the more values of PV, AV and TBAV decreased during cake storage at room temperature. From the same tables it could be observed that, cake control sample gave the higher values of PV, AV and TBAV than cake with different additives as antioxidant. These results are 
Table 1. Antioxidative activity of sage and clove extraction on induction period (hour) at $100^{\circ} \mathrm{C}$

\begin{tabular}{|lcc|}
\hline \multicolumn{1}{|c}{ Samples } & Induction period & Protection factor* \\
\hline Cake $($ control $)$ & 9.0 & 1.0 \\
Cake +100 ppm sage extraction & 16.0 & 1.77 \\
Cake +200 ppm sage extraction & 21.30 & 2.36 \\
Cake +300 ppm sage extraction & 24.70 & 2.74 \\
Cake +100 ppm clove extraction & 15.60 & 1.73 \\
Cake +200 ppm clove extraction & 19.0 & 2.11 \\
Cake +300 ppm clove extraction & 22.15 & 2.46 \\
\hline
\end{tabular}

* Protection factor $=$ induction period of butter with additive / induction period of control

Table 2. Effect of sage and clove extraction on peroxide value of cake samples during storage period*

\begin{tabular}{|lccccc|}
\hline \multicolumn{1}{c}{ Samples } & Zero & 2 weeks & 4 weeks & 6 weeks & 8 weeks \\
\hline Cake (control) & 0.53 & 2.94 & 5.71 & 8.27 & 12.42 \\
Cake + 100 ppm sage extraction & 0.53 & 1.10 & 1.86 & 3.21 & 6.31 \\
Cake + 200 ppm sage extraction & 0.53 & 0.87 & 1.62 & 3.15 & 6.20 \\
Cake + 300 ppm sage extraction & 0.53 & 0.71 & 1.55 & 3.10 & 5.96 \\
Cake + 100 ppm clove extraction & 0.53 & 1.14 & 1.99 & 4.13 & 6.67 \\
Cake + 200 ppm clove extraction & 0.53 & 0.90 & 1.63 & 3.89 & 6.25 \\
Cake + 300 ppm clove extraction & 0.53 & 0.82 & 1.58 & 3.54 & 6.11 \\
\hline
\end{tabular}

* Each value is mean of duplicate determination 
Table 3. Effect of sage and clove extraction on acid value of cake samples during storage period*

\begin{tabular}{|lccccc|}
\hline \multicolumn{1}{|c}{ Samples } & Zero & 2 weeks & 4 weeks & 6 weeks & 8 weeks \\
\hline Cake (control) & 0.89 & 1.05 & 1.08 & 1.09 & 1.13 \\
Cake + 100 ppm sage extraction & 0.89 & 0.99 & 1.02 & 1.05 & 1.05 \\
Cake + 200 ppm sage extraction & 0.89 & 0.97 & 1.01 & 1.03 & 1.04 \\
Cake + 300 ppm sage extraction & 0.89 & 0.97 & 0.98 & 1.00 & 1.02 \\
Cake + 100 ppm clove extraction & 0.89 & 1.04 & 1.07 & 1.08 & 1.11 \\
Cake + 200 ppm clove extraction & 0.89 & 1.02 & 1.05 & 1.08 & 1.10 \\
Cake + 300 ppm clove extraction & 0.89 & 1.00 & 1.04 & 1.06 & 1.08 \\
\hline
\end{tabular}

* Each value is mean of duplicate determination

Table 4. Effect of sage and clove extraction on thiobarbituric acid value of cake samples during storage period*

\begin{tabular}{|lccccc|}
\hline \multicolumn{1}{|c}{ Samples } & Zero & 2 weeks & 4 weeks & 6 weeks & 8 weeks \\
\hline Cake (control) & 0.09 & 0.14 & 1.51 & 1.90 & 2.17 \\
Cake + 100 ppm sage extraction & 0.09 & 0.07 & 0.62 & 1.05 & 1.38 \\
Cake + 200 ppm sage extraction & 0.09 & 0.05 & 0.56 & 0.88 & 1.31 \\
Cake + 300 ppm sage extraction & 0.09 & 0.04 & 0.50 & 0.76 & 1.26 \\
Cake + 100 ppm clove extraction & 0.09 & 0.09 & 0.73 & 1.20 & 1.60 \\
Cake + 200 ppm clove extraction & 0.09 & 0.08 & 0.61 & 1.03 & 1.51 \\
Cake + 300 ppm clove extraction & 0.09 & 0.06 & 0.54 & 0.92 & 1.33 \\
\hline
\end{tabular}

* Each value is mean of duplicate determination 
coincide with obtained by Farag $\boldsymbol{e t}$ al (1989 a\&b), Djarmati et al (1991), Kim et al (1994) and Lim \& Suhaila (1999). On the other side Topallor et al (1997) demonstrated that the rancidity is caused by insertin oxygen in fatty acid double bonds forming peroxides which are decomposed into aldhydes and ketones. On the other hand Farag et al (1989a) declared that the antioxidants suppress the hydrogen atom abstraction from the fatty acid which leads to the decrease of hydroperoxide formation. It is well known that, phenolic compounds act as hydrogen donors to the reaction mixture and therefore, the formation of hydroperoxides is decreased. The slow formation of conjugated dienes and consequently the secondary products by clove oil and its major compounds indicated that these materials acted as hydrogen donors to the peroxy radicals. Thus, retarding the autoxidation of linoleic acid by chain radical termination. In addition the results Gapor et al (1989) demonstrated that during the 8 weeks of storage, PV for cake control samples increased with time, showing that the fat in the cake had oxidized to lipid hydroperoxides. These unstable, primary oxidation products were consequently broken down by a free radical mechanism in which the $\mathrm{O}-\mathrm{O}$ bond was cleaved on either side of the carbon atom bearing the oxygen atom to give the hydroxyl free radical and many types of secondary products such as ketones, alcohols, aldehydes and malonaldehydes which give off-flavors.

In this concept, Allen and Hamilton (1983) reported that the peroxide value is a good index for the quality of fat. A refined fats should have peroxide value of less than 1 milliequivalent $/ \mathrm{kg}$. Fats that have been stored for some period of time after refining may be found to have peroxide value of up to 10 milliequivalents $/ \mathrm{kg}$.

Regarding sensory evaluation of cake after baking (at zero time) the results in Table, (5) declared that, color was gradually decreased. At the same time addition of $300 \mathrm{ppm}$ from sage and clove extraction to cake caused significant different in color compared to control. This finding may be related to sage and clove extraction are brownish-green in color as mentioned by Farrell, (1990). From the same table it could be observed that addition of sage and clove extraction to cake at 100 , 200 and $300 \mathrm{ppm}$ concentration led to slightly improve in flavor and taste compared to control sample. These findings may be attributed to some compounds in clove such as Eugenol, 2 methoxy-4 allyl phenol which gives the pleasant odor and its used for making vanillin synthetically, in the meantime the clove is considered to be the most fragrant of all aromatic spices as mentioned by Farrell, (1990) and he added that oil of clove has some antiseptic qualities and recommended by some dentists as a dental analgesic. It is also used in toothpastes and by pharmacies as a flavoring aid. In the meanwhile when sage and clove extraction added to cake at concentration 100,200 and $300 \mathrm{ppm}$ the values of texture and tenderness not significantly different compared to control. Furthermore Wang et al (2000) reported that although sage is an herb considered mainly for its content of essential oil (it is an aromatic herb), it is largely used as an infusion where polar compounds play a control role. From the same table, it could noticed that texture was improved by addition clove extraction than sage extraction compared to control sample. This improve could be explained due to the 
natural extractive of clove contain mono-, di-, and triglycerides, lecithin and lactic acid and its assist as emulsions by reduction surface tension at the oil-water interface.

With respect to sensory evaluation of cake at the end of storage period ( 8 weeks) by comparing the given results in Table, (5) and Table, (6) deduced that color, texture, tenderness, taste and flavor were some what affected by storage period. These results can be supported by Guenther, (1961) who reported that aroma affected by storage processes due to the loss of some volatile compounds by evaporation, rearrangement, oxidation, polymerization or resinfication.

From the present study it could be concluded that natural antioxidants obtained from sage and clove can be added to prepared cake in order to improve shelf life, avoid deterioration quality and retard oxidative rancidity of cake.

Table 5. Sensory evaluation of cake sample at the beginning of storage period (zero time) at room temperature*

\begin{tabular}{|lccccc|}
\hline \multicolumn{1}{c}{ Samples } & Color & Texture & Tenderness & Taste & Flavor \\
& 10 & 10 & 10 & 10 & 10 \\
\hline Cake $($ control $)$ & $9.5 \mathrm{a}$ & $9.0 \mathrm{a}$ & $9.4 \mathrm{a}$ & $9.0 \mathrm{~b}$ & $9.1 \mathrm{a}$ \\
Cake +100 ppm sage extraction & $9.4 \mathrm{a}$ & $9.2 \mathrm{a}$ & $9.4 \mathrm{a}$ & $9.1 \mathrm{~b}$ & $9.2 \mathrm{a}$ \\
Cake +200 ppm sage extraction & $9.2 \mathrm{ab}$ & $9.3 \mathrm{a}$ & $9.4 \mathrm{a}$ & $9.2 \mathrm{ab}$ & $9.3 \mathrm{a}$ \\
Cake +300 ppm sage extraction & $8.7 \mathrm{~b}$ & $9.4 \mathrm{a}$ & $9.4 \mathrm{a}$ & $9.6 \mathrm{a}$ & $9.5 \mathrm{a}$ \\
Cake +100 ppm clove extraction & $9.3 \mathrm{a}$ & $9.2 \mathrm{a}$ & $9.5 \mathrm{a}$ & $9.1 \mathrm{~b}$ & $9.2 \mathrm{a}$ \\
Cake +200 ppm clove extraction & $9.1 \mathrm{ab}$ & $9.2 \mathrm{a}$ & $9.5 \mathrm{a}$ & $9.3 \mathrm{a}$ & $9.3 \mathrm{a}$ \\
Cake +300 ppm clove extraction & $8.6 \mathrm{~b}$ & $9.3 \mathrm{a}$ & $9.6 \mathrm{a}$ & $9.4 \mathrm{a}$ & $9.3 \mathrm{a}$ \\
\hline
\end{tabular}

* Values within each column with the same superscript letters are not significantly different 
Table 6. Sensory evaluation of cake samples at the end of storage period (8 weeks) at room temperature*

\begin{tabular}{|lccccc|}
\hline \multicolumn{1}{c}{ Samples } & $\begin{array}{c}\text { Color } \\
10\end{array}$ & $\begin{array}{c}\text { Texture } \\
10\end{array}$ & $\begin{array}{c}\text { Tenderness } \\
10\end{array}$ & $\begin{array}{c}\text { Taste } \\
10\end{array}$ & $\begin{array}{c}\text { Flavor } \\
10\end{array}$ \\
\hline Cake (control) & $8.7 \mathrm{a}$ & $7.0 \mathrm{a}$ & $7.0 \mathrm{a}$ & $8.2 \mathrm{~b}$ & $8.0 \mathrm{~b}$ \\
Cake + $100 \mathrm{ppm}$ sage extraction & $8.5 \mathrm{a}$ & $7.1 \mathrm{a}$ & $7.0 \mathrm{a}$ & $8.5 \mathrm{ab}$ & $8.2 \mathrm{~b}$ \\
Cake + $200 \mathrm{ppm}$ sage extraction & $8.2 \mathrm{~b}$ & $7.1 \mathrm{a}$ & $7.1 \mathrm{a}$ & $8.6 \mathrm{a}$ & $8.5 \mathrm{ab}$ \\
Cake + $300 \mathrm{ppm}$ sage extraction & $7.2 \mathrm{c}$ & $7.2 \mathrm{a}$ & $7.3 \mathrm{a}$ & $8.9 \mathrm{a}$ & $8.9 \mathrm{a}$ \\
Cake+100 ppm clove extraction & $8.4 \mathrm{a}$ & $6.9 \mathrm{a}$ & $7.0 \mathrm{a}$ & $8.3 \mathrm{~b}$ & $8.1 \mathrm{~b}$ \\
Cake+200 ppm clove extraction & $8.3 \mathrm{ab}$ & $7.0 \mathrm{a}$ & $7.2 \mathrm{a}$ & $8.4 \mathrm{ab}$ & $8.2 \mathrm{~b}$ \\
Cake+300 ppm clove extraction & $7.1 \mathrm{~b}$ & $7.2 \mathrm{a}$ & $7.3 \mathrm{a}$ & $8.6 \mathrm{a}$ & $8.5 \mathrm{a}$ \\
\hline
\end{tabular}

* Values within each column with the same superscript letters are not significantly different.

\section{REFERENCES}

Allen, J.C. and R.J. Hamilton (1983). Rancidity in Foods., pp. 85 and 173. Applied Science Publishers, London.

Amerine, M.A.; R.M. Danglorn and E.B. Roessler (1965). Principles of Sensory Evaluation of Food., pp. 24-26. Academic Press, New York.

AOAC, (1995). Association of Official nalytical Chemists. Official Methods of Analysis $16^{\text {th }}$ Ed., International, Arlington, Virginia, USA.

Banias, C.; V. Oreopoulou and C. Thomopoulus (1992). The effect of primary antioxidants and synergists on the activity of plant extracts in lard. $\boldsymbol{J}$. $\mathbf{A m}$. Oil Chem. Soc. 69: 520-524.

Djarmati, Z.; R.M. Jankov; E. Gapor, M.; A. Ong; A. Kato; H. Schwirtlich; B. Djulinac and A. Watanabe and T. Kawada (1989). AnDjordjevic (1991). High antioxidant ac- tivity of extracts obtained from sage by supercritical $\mathrm{Co}_{2}$ extraction. J. Am. Oil. Chem. Soc., 68(10): 731-734.

Farag, R.S.; A.Z. Badei; F.M. Hewedi and G.S. EL-Baroty (1989a). Antioxidant activity of some speice essential oils on linoleic acid oxidation in Aqueous media. J. Am. Oil. Chem. Soc., 66(6): 792-799.

Farag, R.S; A.Z. Badei and G.S. ElBaroty (1989b). Influence of thyme and clove essential oils on cottonseed oil oxidation. J. Am. Oil. Chem. Soc. 66(6): 800-804.

Farrell, K.T. (1990). Spices, Condiments and Seasonings. $2^{\text {nd }} E d$., p. 76 and p. 188. The AVI publishing CO., Inc. Westport, Connecticut., USA. tioxidant activities of palm vitamin $\mathrm{E}$ 
with special reference to tocotrienols. The International . J. of Palm Oil Research \& Development 1 (1): 63-67.

Guenther, M. (1961). The Essential Oils. $4^{\text {th }} \boldsymbol{E}$., p. 96. D. Van Nostrand Company, Inc., Princeton, New York.

Karin, S. and E. Hedda (1996). Evaluation of antioxidative constituents from thyme. J. Sci. Food and Agric. 70 (1): 217-223.

Kim, S.Y.; J.H. Kim; S.K. Kim; M.J. Oh and M.Y. Jung (1994). Antioxidant activities of selected oriental herb extracts. J. Am. Oil. Chem. Soc. 71(6): 633-640.

Lim, P.L. and M. Suhaila (1999). Antioxidative and antimycotic effects of turmeric, Lemon-grass betel leaves, clove, black pepper leaves and garcinia atriviridis on butter cakes. J. Sci. Food and Agric. 79: 1817-1822.

Mochida, K.; M. Goto and K. Saito (1986). Human cell cultures as an assay for the toxicity of antioxidants. Bull. Environ. Contam. Toxicol. 35: 427-429.
Saito, Y. (1977). Antioxidants in cloves J. Am. Oil Chem. Soc. 62:1-6. SAS (1996). Statistical Analytical System. SAS User's Guide: Statistics SAS Institutie Inc. Editors, Cary, NC. 2751280000, USA.

Smith, R.J.; M.L. Winder and G. Medicinal (1996). In: The National Herb Garden Guidebook., pp. 61-71. Ober, R., Ed.; The Herb Society of America, Inc. Springfield, VA., USA.

Topallor, H.;Y. Bagrak and M. Iscan (1997). A Kinetic study on the autoxidation of sunflower oil. J. Am. Oil Chem. Soc., 74(10): 1323-1327.

Velioglu, Y.S.; G. Mazza; L. Gao and B.D. Oomah (1998). Antioxidant activity and total phenolics in slected fruits, vegetables and grain products. J. Agric. Food Chem. 46: 4113-4117.

Wang, M.; H. Kikuzaki; N. Zhu; S.Sang and N. Nakatani (2000). Isolation and structural elucidation of two new glycosides from sage (Salvia officinalis L.). J. Agric. Food Chem. 48: 235-238. 
بحلة اتحاد الجامعات العربية للدراسات والبحوث الزراعية ، جامعة عين شمس ، القاهرة ، 13(2) ، 341 - 350 ، 2005

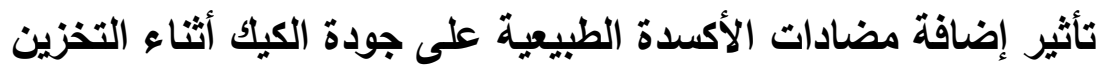

$$
\begin{aligned}
& \text { أيمن عزت محمد } 1 \text { - ناديه محمود عبد المطلب } 1
\end{aligned}
$$

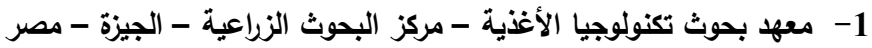

[21]

إلـى إطالـة فترة ثبـات الزبـد وتـأخير التـزنخ

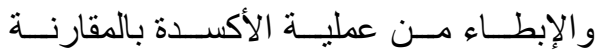

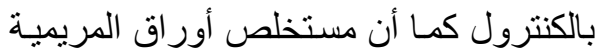

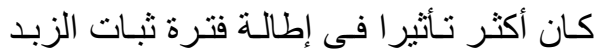

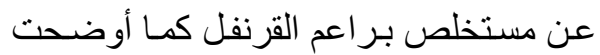

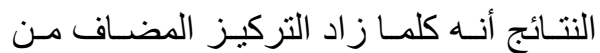

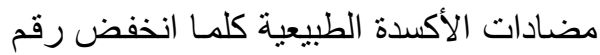

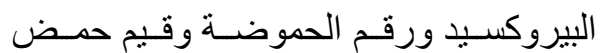

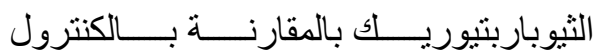

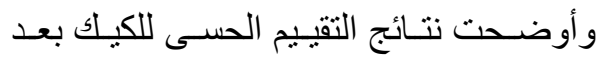

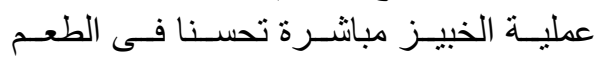

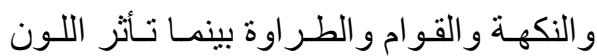

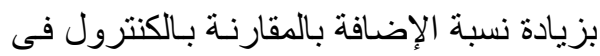

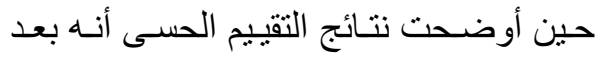

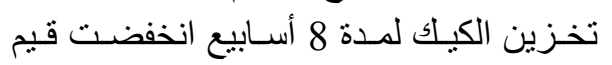
التقييم الحسى بصفة عامة.

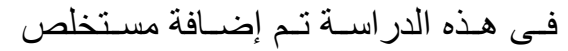

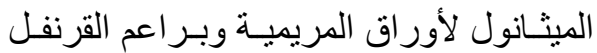
كمصادر لمضادات الأكسدة الطبيعية بتركيز

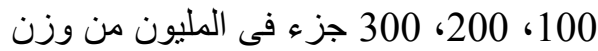

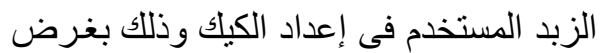
حفظ جودة الكيك أثناء التخزين وتأخير عملية

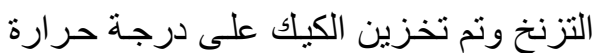
الغرفة لمدة 8 أسـابيع وتم قياس ثبات البـات الدهن

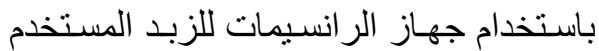

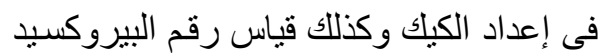

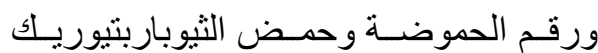
وكذلك التقييم الحسى بعد الخبيز مباثرة (قبل

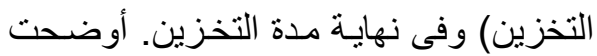

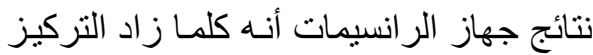

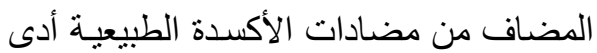

